\title{
A DISTINÇÃO LEGALIDADE-MORALIDADE NA CRÍTICA DE HEGEL A KANT
}

\author{
Idalgo Jose Sangalli ${ }^{1}$ \\ Universidade de Caxias do Sul (UCS) \\ Mateus Salvadori ${ }^{2}$ \\ Universidade de Caxias do Sul (UCS) \\ https://orcid.org/0000-0002-9445-6206
}

\section{RESUMO:}

Este artigo tem como objetivo tratar da crítica de Hegel a Kant a partir da distinção entre legalidade e moralidade. Enquanto Kant permanece preso ao formalismo, Hegel aponta princípios conteudísticos, pois considera que somente a partir deles é possível estabelecer deveres particulares. Kant define o certo, o bem e o justo a partir de um procedimento que visa à universalidade. A distinção entre legalidade e moralidade é realizada a partir de seus móbeis. A razão, em Kant, não é legisladora, pois não está preocupada com "o que deve ser feito", mas "como deve ser feito". O imperativo categórico é regulador e orientador. Já Hegel critica o formalismo da teoria kantiana. A eticidade tem como grande objetivo a libertação da indeterminação, da imediatez e do natural. Isso ocorre instaurando-se a mediação e produzindo, consequentemente, a determinação (nas instituições sociais).

PALAVRAS CHAVES: Legalidade; Moralidade; Kant; Eticidade; Liberdade; Hegel.

\section{THE DISTINCTION LEGALITY-MORALITY IN THE CRITICAL OF HEGEL TO KANT}

\footnotetext{
${ }^{1}$ Doutor em Filosofia pela Pontifícia Universidade Católica do Rio Grande do Sul (PUCRS), Rio Grande do Sul - Brasil. Professor do PPG Filosofia na Universidade de Caxias do Sul (UCS), Rio Grande do Sul - Brasil. E-mail: ijsangal@ucs.br

${ }^{2}$ Doutor em Filosofia pela Pontifícia Universidade Católica do Rio Grande do Sul (PUCRS), Rio Grande do Sul - Brasil. Professor de Filosofia na Universidade de Caxias do Sul (UCS), Rio Grande do Sul - Brasil. E-mail: mateusche@yahoo.com.br
} 


\begin{abstract}
:
This article has the objective to treat the critical of Hegel to Kant from the distinction between legality and morality. While Kant remains stuck to the formalism, Hegel points the relative principles to the content, because only from them can be established particular duties. Kant defines the right, good and fair from a procedure that aims at the universality. The distinction between legality and morality is made from their mobiles. The reason, in Kant, is not legislator because it is not worried about with "what should be done" but "how it should be done." The categorical imperative is the regulator and supervisor. Hegel criticizes the formalism of Kantian theory. The ethicity has as its major objective the liberation of indeterminacy, the immediacy and the natural. This occurs by introducing mediation and producing and producing, thereby, the determination (social institutions).
\end{abstract}

KEYWORDS: Legality; Morality; Kant; Ethicity; Freedom; Hegel.

\title{
1.Considerações introdutórias
}

Que o homem é um animal político, já o atestou Aristóteles. Viver, enquanto indivíduo, isolado de seu semelhante, parece ser uma agressão à natureza humana que comporta e exige a convivência com o outro. Nesse compartilhar dos espaços, coisas e ideias surgem pequenos e grandes conflitos. Intenções e ações particulares se efetivam e chocam-se com outras intenções e ações expressas por outras vontades particulares livres. Isso exige regras de conduta para ordenar e possibilitar a convivência harmoniosa entre os indivíduos.

Mesmo com as regras vigentes, as normas jurídicas e os contratos existentes, por si sós, não garantem o acordo harmonioso entre os seus participantes. Isso significa que há necessidade de um terceiro elemento para resolver os possíveis conflitos. Constituir um Estado com a finalidade de guardar o direito dessas vontades individuais livres é a proposta kantiana.

Também para Hegel, tal interventor é representado pelo Estado, que é o lugar da substancialidade ética, um lugar que apresenta a ideia de um Estado ético no qual as vontades e as liberdades estão reconhecidas, os direitos e os deveres são preservados e assumidos e em que se efetiva, enfim, a justiça na perspectiva social.

O que se pretende abordar aqui é a relação e a passagem entre duas esferas, a da moralidade e a da legalidade, que estão subjacentes em qualquer intenção e ação humanas e que remetem para o dualismo indivíduo-sociedade. 
O pano de fundo que move esta abordagem se expressa no problema de se é possível apenas guiar nossas ações pelo aspecto legal e, assim mesmo, garantir decisões moralmente válidas e justas ou cairíamos no mero legalismo? $\mathrm{O}$ pano de fundo que move essa abordagem se expressa no problema relativo à possibilidade de guiar nossas ações ainda que apenas pelo aspecto legal e, assim mesmo, garantir decisões moralmente válidas e justas, ou buscar outras alternativas para não cair no mero legalismo? Que posição ocupa o Direito frente à Moralidade? Qual a posição, ou melhor, a crítica e proposta de Hegel frente à distinção kantiana entre moralidade e legalidade? Mais especificamente, a boa vontade "subjetiva" é suficiente? Por outro lado, o indivíduo autônomo não ficaria, talvez, abafado pela vontade substancial representada pelo Estado?

$\mathrm{Na}$ tentativa de compreender melhor essas relações e apontar possíveis respostas, é oportuno, primeiramente, apresentar uma breve reconstrução de alguns conceitos básicos da ética kantiana. A análise deter-se-á na distinção entre a moralidade e a legalidade, apresentada por Kant, nas obras Fundamentação da Metafísica dos Costumes e Crítica da Razão Prática. Essa tematização é necessária em virtude da posição assumida por Hegel frente à filosofia ética kantiana. O passo seguinte é marcado pela exposição das principais linhas da ética hegeliana, apresentadas na obra Filosofia do Direito. É a tentativa de, com Hegel, responder aos questionamentos e dúvidas surgidas a partir da própria teoria ética.

As considerações feitas não têm a pretensão de esgotar o assunto, mas apenas a de estabelecer e recolocar mais explicitamente algumas relações que, possivelmente, podem ser ampliadas e aprofundadas.

\section{A lei moral kantiana}

Com a obra Crítica da Razão Prática, em geral, inversamente à da Crítica da Razão Pura, Kant procura afastar a razão empiricamente condicionada que pretende ser o fundamento único e exclusivo de determinação da vontade desse ser racional finito, mergulhado na sensibilidade que necessita de princípios a priori para orientar as suas ações e conduta. Aqui, o âmbito noumênico, que era inacessível na Crítica da Razão Pura, torna-se acessível na Crítica da Razão Prática ${ }^{3}$. Está, também, sempre operando por princípios $a$

3 A obra citada, como metafísica dos costumes, trata das leis, daquilo que deve ser, o dever ser, conforme o dever moral. Através do método transcendental, Kant busca aqui responder à questão: Como é possível a obrigação moral? E, num plano já alcançado na CRPura, como são possíveis os juízos sintéticos a priori práticos? 
priori, via vontade pura, expressa na fórmula do imperativo categórico que é, em última análise, fato da razão. Afirma que "Esta analítica mostra que a razão pura pode ser prática, isto é, determinar a vontade por si mesma, independentemente de todo o elemento empírico - e mostra isso mediante um facto (Faktum) em que a razão pura se evidencia efectivamente em nós como prática, determinando por este meio a vontade à ação" (KANT, 1989, p. 54).

Sendo o homem razão e sensibilidade, ou melhor, razão e vontade, que não coincidem necessariamente, é imperativo o dever como critério a ser usado pela vontade, a boa vontade (KANT, 1992, p. 21-26) dirigida pela razão prática frente às inclinações, ao que vem de fora, que determinam as ações contrárias às regras da própria razão. Esse faktum puro da razão determina e dá a conhecer uma lei universal, ou seja, a lei moral (sittengesetz). Na obra Crítica da Razão Prática, Kant sustenta que

\begin{abstract}
A lei moral também nos é dada, de certo modo, como um facto, Faktum, da razão pura, de que somos conscientes a priori e que é apodicticamente certo, supondo mesmo que não se pudesse encontrar na experiência exemplo algum em que ela fosse exactamente observada. Por conseguinte, a realidade objectiva da lei moral não pode ser demonstrada por nenhuma dedução, nem por todo o esforço da razão teórica, especulativa ou empiricamente sustentada; e, por consequência, mesmo se se quisesse renunciar à certeza apodíctica, também não pode ser confirmada pela experiência e assim ser demonstrada a posteriori; e, apesar de tudo, mantém-se firme por si mesma.(KANT, 1989, p. 59-60).
\end{abstract}

A lei moral, embora sendo um dos princípios práticos, isto é, das determinações gerais da vontade, pertencendo ao grupo dos imperativos e não das máximas subjetivas, se diferencia das prescrições práticas enquanto regras de habilidade e conselhos de prudência. Isso porque só os princípios práticos objetivos, isto é, válidos para qualquer ser racional, chamados de imperativos, são representados como um dever (sollen), como uma obrigação para a vontade que é determinada por representações objetivas da razão e não por causas subjetivas. Tais imperativos devem ser categóricos e não hipotéticos, pois seriam aqueles que nos representariam "[...] uma ação como objetivamente necessária por si mesma, sem relação com qualquer outra finalidade" (KANT, 1992, p. 50), valendo apenas para a natureza humana finita. Afirma Kant (1992, p. 49), "Por isso os imperativos não valem para a vontade divina nem, em geral, para uma vontade santa; o dever (sollen) não está aqui no seu lugar, porque o querer coincide já por si necessariamente com a lei”. 
Os imperativos categóricos são leis morais em que o mero querer independente de todas as condições subjetivas é determinado pela regra da razão de maneira a priori, resultando em princípios práticos universais e necessários. É uma vontade determinada aprioristicamente pela lei, pela forma da lei e não por objetos, pela matéria. A razão pura deve por si mesma ser prática sem pressuposição das inclinações. A lei moral nunca pode ser buscada em exemplos para não cair no ponto de vista material, do conteúdo da lei. Portanto, se o imperativo categórico não deve ser determinado pelos conteúdos da lei, então a sua validade universal, enquanto lei moral, é determinada unicamente pela forma da lei, conforme pode ser verificado facilmente no parágrafo 4, teorema III, da Crítica da Razão Prática. Assim, o imperativo categórico não diz o que deve fazer, mas afirma o como deve ser.

Isso remete para o âmbito da intenção. $O$ que interessa aqui não é que o objeto querido tenha o qualificativo de bom e, assim, o princípio determinante seria moralmente bom. O que importa é que o ato moral não depende do objeto pretendido, do fim a ser atingido ou das vantagens possíveis, mas do princípio, da intenção pela qual queremos tal objeto, isto é, agir só por dever e, portanto, por respeito à lei. A vontade deve determinar-se imediatamente a si mesma pela representação da ação. Se ficar no nível da matéria, será uma vontade mediada. Em outras palavras, a "autonomia da vontade é aquela sua propriedade graças à qual ela é para si mesma a sua lei (independentemente da natureza dos objetos do querer)" (KANT, 1992, p. 85). Esta definição, enquanto faculdade de dar leis a si mesmo, é um dos pontos que caracteriza a moralidade. Mais adiante isso será retomado.

Assim, absolutamente boa e sem restrição, a vontade deve considerar as normas, as ações legais universais como, por exemplo, uma das formulações do imperativo categórico: "Devo proceder sempre de maneira que eu possa querer também que a minha máxima se torne uma lei universal" (KANT, 1992, p. 33). Aqui, a exigência que Kant apresenta como único princípio de determinação de uma ação para ser moralmente válida é a de universalidade. Isso, é claro, tendo sempre em conta que a vontade só deve ser determinada pela mera forma da lei, que, em última análise, é dada pela razão pura, independente de fins particulares, de conteúdos empíricos ou do princípio da felicidade. É a distinção kantiana entre autonomia e heteronomia.

Através da pura ideia de liberdade, que é um pressuposto e condição de possibilidade do imperativo categórico, Kant aponta o fundamento da moralidade. A realidade objetiva da liberdade não pode ser conhecida e comprovada pela experiência empírica, mas "vale somente como pressuposto necessário da razão" (KANT, 1992, p. 111). E ainda, enquanto eu fenomênico, 
não sou livre por estar determinado pelas leis da natureza, mas, como noumeno, posso ser livre, pois remete à autonomia da vontade, enquanto capacidade de independência e de autodeterminação em relação aos conteúdos da lei moral. A vontade cria suas próprias leis. Torna-se possível conceber a vontade pura como causa livre, isto é, como leis da liberdade. Diz Kant no teorema IV, da Crítica da Razão Prática: "Mas essa independência é a liberdade em sentido negativo, e essa legislação própria da razão pura e, como tal, prática, é a liberdade em sentido positivo" (KANT, 1989, p. 45). A ideia da liberdade, que é transcendental e, portanto, prática e a priori, surge a partir da moralidade, embora essa só se efetive pela liberdade. Lei prática incondicionada e liberdade estão entrelaçadas e necessariamente dependentes ${ }^{4}$.

\subsection{0 ato moral e o legal}

O próximo passo trata da distinção entre moralidade e legalidade, levando em conta a concepção da tradição do jusnaturalismo e iluminismo alemão, os quais Kant acompanhou, que separa a moral e o direito como forma de limitar o poder do Estado. O reconhecimento de que o direito, enquanto forum externum, em forma de lei representando a vontade do Estado, deveria evitar adentrar-se no âmbito da consciência individual, isto é, no que diz respeito à liberdade dos indivíduos em nível de assuntos de forum internum (BOBBIO, 1984, p. 57).

Como foi exposto acima, para que uma ação seja moral, ela deve ser realizada somente para obedecer à lei do dever, não sendo condicionada por um fim, seja ele qual for, e sim pela máxima que a determina exclusivamente pelo princípio da vontade, movida pelo mero respeito à lei ${ }^{5}$. Em outras palavras, só é moral a ação realizada por dever. Por outro lado, a ação realizada em conformidade ao dever, sendo determinada não pelo mero respeito ao dever, mas por inclinações ou máximas subjetivas, caracteriza o campo da mera legalidade. Essa distinção formal, enquanto forma da obrigação ou diferentes motivos que responde ao como da mesma ação, é a base da diferença entre legislação moral (interna) e legislação jurídica (externa) (BOBBIO, 1984, p. 54$55)^{6}$.

4 Para um melhor estudo da questão da liberdade em Kant, é clara a terceira secção da Fundamentação da Metafísica dos Costumes e, também, o primeiro capítulo Dos princípios da razão pura prática, do problema II, os teoremas III e IV, da CRPrática.

5 Cf. Fundamentação da Metafísica dos Costumes, p. 27-33 e CRPrática, no escólio da Definição do primeiro capítulo, p. 30.

6 Ainda nesta obra, um pouco mais adiante (p.56-57), Bobbio sugere que os atributos interno e externo frente à distinção entre moralidade e legalidade seja entendida, como: "a ação legal é 
Kant também distingue a moralidade da legalidade no que se refere ao fundamento e condição dos princípios práticos morais, ou seja, a liberdade. A liberdade pode ser interna, e então teremos a liberdade moral, ou externa, que aponta para a liberdade jurídica. Liberdade, então, significa não impedimento, tanto na esfera moral como na esfera da liberdade jurídica. Essa distinção são momentos da mesma liberdade. Na primeira, como liberação interior, no sentido de eliminar as inclinações e interesses subjetivos, que também são frutos de nossa vontade, restringindo-se apenas na adequação das leis fornecidas pela razão pura. É uma autolegislação da razão pura prática, uma espontaneidade de agir pela própria razão, de seu uso interno. Quanto à segunda, como liberação exterior, isto é, a possibilidade do sujeito agir no nível de convivência com outras vontades humanas, também igualmente livres, de maneira tal que não seja afetado pela ação dessas vontades alheias. Também é uma autolegislação da razão, enquanto arbítrio que deve estar em conformidade com a lei da própria razão pura prática para tornar-se livre. É um agir, pelo livre arbítrio, nas relações interpessoais no seio da sociedade civil. No sentido mais preciso, como destaca Bobbio, a moralidade, enquanto liberdade interna, referese "a uma relação de mim consigo mesmo" e o direito, enquanto liberdade externa, refere-se "a uma relação minha com os outros.” Respectivamente, “[...] quero dizer - se interpretamos bem o pensamento de Kant - que sou responsável por aquela ação somente diante de mim mesmo (...) igualmente (...) que sou responsável por aquela ação frente aos outros". Essa última é entendida como representação concreta da vontade coletiva no Estado. (BOBBIO, 1984, p. 59-60).

Considerando a diferença existente entre os deveres e as ações, que não devem ser confundidas, como alerta Bobbio, já que a "[...] legislação moral não é a que prescreve deveres com relação a si mesmo, mas aquela por cujo cumprimento somos responsáveis somente frente a nós mesmos", e, por sua vez, a "[...] legislação jurídica não é a que prescreve deveres com relação aos outros, mas aquela por cujo cumprimento somos responsáveis frente à coletividade". (BOBBIO, 1984, p. 60). Isso nos leva a relações entre sujeitos,

externa pelo fato de que a legislação jurídica, dita portanto legislação externa, deseja unicamente uma adesão exterior às suas próprias leis, ou seja, uma adesão que vale independentemente da pureza da intenção com a qual a ação é cumprida, enquanto a legislação moral, que é dita, portanto, interna, deseja uma adesão íntima às suas próprias leis, uma adesão dada com intenção pura, ou seja com a convicção da bondade daquela lei. Disso se segue que o dever jurídico pode ser dito externo, porque legalmente eu sou obrigado somente a conformar a ação e não também a intenção com a qual cumpro a ação, segundo a lei; enquanto o dever moral é dito interno, porque moralmente eu sou obrigado não somente a conformar a ação mas também a agir com pureza de intenção". 
destacadas por Kant, que acabam caracterizando a relação jurídica no binômio direito-dever possíveis apenas entre seres humanos. Nessa relação com os quais devo, sou obrigado a ser responsável diante dos outros, isto é, os outros sujeitos têm o direito e o poder de exigir que eu cumpra com a minha obrigação (direito subjetivo). Ainda com Bobbio, “[...] a experiência jurídica é caracterizada pela correspondência de um direito a um dever e, reciprocamente, de um dever a um direito, ou pela presença simultânea de um dever de um lado e de um direito do outro: o que se chama relação jurídica". (BOBBIO, 1984, p. 61). Então, a minha liberdade interna, que representa a moral, está independente do direito dos outros seres racionais, pois é apenas a adequação à lei da minha razão. Por sua vez, o campo da legalidade, que é o da liberdade externa, tem que levar em conta a relação direito-dever dos outros. O arbítrio deve ser limitado, assim como as inclinações, os impulsos subjetivos, pelo direito para garantir o exercício e a possibilidade da liberdade e da igualdade universal.

Outros dois critérios ${ }^{7}$ que possibilitam a distinção entre moral e direito são a dicotomia autonomia-heteronomia e a distinção entre imperativos categóricos e hipotéticos. Foi exposto acima que a vontade moral deve ser autônoma, isto é, capaz de dar leis a si mesma. Portanto, é a vontade pura como liberdade interna. Quanto à heteronomia, que caracteriza uma vontade determinada por inclinações ou interesses no nível material ${ }^{8}$, ela parece apontar para a dimensão da liberdade externa em que a vontade jurídica seria a ela pertencente. Em outras palavras, se a intenção não for pelo mero respeito à lei moral, qualquer outro motivo, sendo por coação ou não, por medo ou pela obrigação imposta por outros indivíduos de igual liberdade externa, a ação, mesmo em conformidade com a lei, será apenas legal, determinada por essa vontade heterônoma. Para obter a adesão livre da vontade, no sentido de uma intenção fornecida via liberdade interna, é mister ser uma vontade autônoma. Em função da estreita relação existente, aqui é possível deduzir (BOBBIO, 1984, p. 65-66) que também com os imperativos surge a mesma distinção. Portanto, os imperativos categóricos representam o âmbito da moral e os imperativos hipotéticos o âmbito jurídico.

7 Bobbio (1984, p. 62) apresenta ainda dois critérios, além dos critérios explícitos da forma da obrigação, como legislação interna e externa e a liberdade como interna e externa, que estariam implícitos na argumentação kantiana na distinção entre moralidade e legalidade.

8 Kant conceitua a heteronomia, na obra Fundamentação da Metafísica dos Costumes (1992, p. 86), da seguinte forma: "Quando a vontade busca a lei, que deve determiná-la, em qualquer outro ponto que não seja a aptidão das suas máximas para a sua própria legislação universal, quando, portanto, passando além de si mesma, busca essa lei na natureza de qualquer dos seus objectos, o resultado é então sempre heteronomia". 
A partir dessa sintética reconstrução de alguns pontos da ética kantiana, convém passar agora para a ética hegeliana. Cabe analisar, a seguir, a posição de Hegel frente à distinção entre moralidade e legalidade, seguindo o princípio orientador que é a ideia da liberdade no seu processo de autodeterminação, galgado nos diferentes momentos em busca de sua plena realização.

\section{A realização da ideia da vontade livre}

Como o próprio título afirma, essa é a meta a ser alcançada por Hegel na obra Filosofia do Direito 9 . É o âmbito do Espírito Objetivo, agora não mais como subjetividade, que, através de sucessivos movimentos e etapas dialéticas, procura mediar a vontade, isto é, efetivar a realização da liberdade na ordem intersubjetiva do todo social. A ideia da liberdade se realiza através do conceito do direito. Tal ideia é o princípio fundador e orientador das estruturas jurídicas (WEBER, 1993, p. 46). Weber complementa, afirmando que "O espírito objetivo ou a Filosofia do Direito não é senão a esfera da liberdade e sua concretização. A liberdade, como conceito, deve desenvolver-se como objetividade. É o princípio universal a ser concretizado, nas distintas formas da ciência do direito" (1993, p. 52). Hegel entende o direito como condição de possibilidade e de realização da liberdade concretamente mediada e efetivada no todo social. Realização objetiva, concreta da liberdade, através das determinações do próprio conceito do direito, que é produto da razão. Esse será o desenvolvimento do espírito objetivo, nas diversas formas do direito,

9 Hegel, em sua filosofia jurídica, não se posiciona radicalmente contra o jusnaturalismo, mas lhe dá outro sentido ou uso. Um dos pontos contrário está em torno do conceito de totalidade ética, que atinge os pressupostos dos sistemas de direito natural e, também, o abandono da ideia do contrato social por ser impossível como instância ética. É no Estado que se concretiza a Ética. Hegel não é contratualista, mas aos moldes de Rousseau, como afirma Bobbio, mostra-se como jusnaturalista, ao defender o Espírito do Povo, como leis naturais e faz, assim, a plena realização desta filosofia. Cf. BOBBIO, na obra Estudos sobre Hegel: Direito, Sociedade Civil, Estado, p. 23-55. Na obra Princípios da Filosofia do Direito, Hegel procura mostrar as determinações e a realização da Ideia da liberdade como princípio orientador e fundante das estruturas concretas do direito. Não trata de uma ciência do direito, que é apenas descritiva, mas propõe uma ciência filosófica do direito que é normativa ,e é ela que fornece ao Direito a ideia da liberdade que é pressuposta como dada. Diz Hegel, na Introdução, no primeiro parágrafo: "La ciencia filosófica del derecho tiene por objeto la Idea del Derecho, es decir, el concepto del derecho y su realización." (p. 55). E no segundo parágrafo: "La ciencia del derecho es una parte de la filosofía. [...] Por ser una parte, tiene un punto de partida determinado, que es el resultado y la verdad de lo que precede, y que constituye lo que se denomina demostración del mismo. El concepto del derecho queda, pues, en cuanto a su devenir, fuera de la ciencia del derecho; su deducción está aquí supuesta, y el concepto mismo debe aceptarse como dado" (p.56). 
enquanto determinações processuais em diversas fases na realização do conceito de liberdade. Liberdade, entendida por Hegel, como superior à liberdade natural e à liberdade dos meros caprichos e inclinações.

O homem é um ser capaz de fazer valer a sua vontade própria, de autodeterminar-se racionalmente. Hegel concebe a liberdade estreitamente vinculada à vontade (wille) e, portanto, diferente do desejo (wunsch). A vontade só é livre, não como arbítrio que deve ser superado, quando se autodetermina e carrega a razão para compreender a sua particularidade, enquanto indivíduo e integrado no tecido social. Na obra Princípios da Filosofia do Direito, Hegel afirma que "El peso constituye el cuerpo y es el cuerpo. Lo mismo ocurre con la libertad y la voluntad, pues lo libre es la voluntad. Voluntad sin libertad es una palabra vacía, y a su vez la libertad sólo es real como voluntad, como sujeto." (HEGEL, 1988, § 4, agregado, p. 67). No ápice do espírito subjetivo, isto é, na liberdade, surge a necessidade de que esta, enquanto pensamento, se objetive, se faça realização concreta, se dê um objeto. É preciso a unidade do teórico com o prático para a concretização do conceito da vontade livre como autodeterminação, como liberdade.

Sendo a ideia da liberdade um pensamento, e o conceito de vontade necessite do pensamento - é o conceito homem como ser racional - então o pensamento é a expressão da vontade que, em última análise, é a vontade livre, isto é, o homem é liberdade, que só se realiza concretamente no bojo das instituições jurídicas, ou melhor, no Estado. "El terreno del derecho es lo espiritual: su lugar más preciso y su punto de partida es la voluntad, que es libre, de modo tal que la libertad constituye su sustancia y determinación, y el sistema del derecho es el reino de la libertad realizada, el mundo del espíritu que se produce a partir de sí mismo como una segunda naturaleza." (HEGEL, $1988, \S 4$, p. 65).

Os momentos do processo de realização da liberdade que, em última análise, é o próprio conceito filosófico do direito, vão revelar, no âmbito em que o espírito deve se objetivar, se dar um objeto, a idéia hegeliana do ethos imanente na vida, isto é, na realização da história nas diversas instituições sociais, como: a família, a sociedade, nos costumes do povo e nas leis do Estado. Nas palavras de Hegel: "Cuando hablamos de derecho no aludimos meramente al derecho, sino también a la moralidad, la eticidad y la historia mundial." (HEGEL, 1988, § 33, agregado, p. 96) ${ }^{10}$.

10 A partir desse sentido, Bobbio considera, e essa é uma das razões em que a posição de Hegel no direito é ambígua. As outras duas razões são, respectivamente, a sistematização dada por Hegel ao direito e as divergências entre os diversos momentos na construção do sistema. Porém, diz Bobbio: "Mas todas estas ambigüidades revelam uma mais profunda: a atitude de atração- 
A seguir, uma breve exposição dos três momentos da caminhada na realização da liberdade, enquanto ideia da vontade livre que, de abstrata deve, através das mediações, constituir-se em vontade substancial.

\subsection{0 direito abstrato (Recht)}

O Espírito deve iniciar o movimento dialético, agora não mais como subjetivo, mas concretizar-se no mundo, tornar-se objetivo, através de seu primeiro momento, o direito abstrato e formal. Aqui, Hegel dá o início à caminhada na realização da liberdade, enquanto ideia da vontade livre. Esse é o nível das instituições jurídicas, nas quais a vontade livre realiza-se de maneira imediata, isto é, com total ausência de determinação e de mediação. O direito abstrato "[...] apresenta as formas concretas e imediatas da realização da ideia da liberdade, que é o fio condutor do direito. [...] São, portanto, formas indeterminadas, porque não existe mediação social. [...] Trata-se de um direito que se efetua na esfera das relações interpessoais e é, assim, privado." (WEBER, 1993, p. 63-64). A sociedade civil e o Estado, assim como a própria família, pertencem ao segundo e terceiro momento da tríade dialética da realização da liberdade e não podem ser considerados aqui ${ }^{11}$.

A noção de pessoa do direito que, juridicamente, é o indivíduo com capacidade jurídica, com direitos e deveres iguais a todas as demais pessoas, é introduzida por Hegel. Sendo um conceito abstrato, o ser-pessoa deve ser buscado, inicialmente, na posse de algum objeto exterior, passando, a seguir, por outras formas de direito até chegar, no final, a tornar-se cidadão do Estado.

Quais são as formas concretas e imediatas do direito abstrato? A vontade livre deixa de ser abstrata no momento em que procura concretizar-se através de sua existência, no primeiro contato com as coisas exteriores, com o mundo sensível. Afirma Hegel, "Este primer modo de la libertad es lo que conocemos como propiedad, es la esfera del derecho formal y abstracto, a la que también pertenecen la propiedad en su figura mediada, como contrato, y el derecho en cuanto lesionado, como delito y pena."(HEGEL, 1988, § 33, agregado, p. 97).

As formas concretas e imediatas da vontade livre se realizam, inicialmente, no direito de posse, que é a primeira forma imediata e exterior da liberdade. No direito de troca é onde deve haver o reconhecimento de outra

repulsa diante do jusnaturalismo". (BOBBIO, 1981, p. 93). Para uma análise mais completa, na mesma obra, p. 57-93.

11 Na obra Principios de la filosofia del derecho, § 40, p. 105-106, é onde Hegel critica a confusa divisão kantiana de direitos reais, pessoais e pessoais reais em que mistura o direito das relações substanciais com o direito da mera personalidade abstrata. 
vontade para garantir o direito de posse formalizado no contrato como propriedade privada. Consequentemente, a própria relação de liberdade mediada pela propriedade, considerada no contrato, entre as vontades participantes, vai possibilitar que se reconheçam como pessoas e proprietários. Exercendo essa liberdade, que o direito de posse e o contrato possibilitam, pode surgir uma vontade particular que discorde e rompa o acordo jurídico e provoque, assim, injustiças. Daí a necessidade da pena para restaurar o direito de tratar a pessoa como pessoa.

Portanto, o que falta no direito abstrato, para superar o caráter relativo e contingente de conteúdos não-refletidos que envolvem vontades particulares imediatas, é a sua universalização (WEBER, 1993, p. 75). É a busca da realização universal da liberdade, como forma de evitar as injustiças, que são fruto de vontades livres formais, que, com a mera relação jurídica do contrato, não garante o respeito universal da vontade alheia. $\mathrm{Na}$ medida em que a realização da liberdade vai se concretizando, vai desaparecendo o elemento qualificativo das coisas, isto é, a abstração da base material. A importância está no nível do espírito e não das coisas. O que interessa é o desenvolvimento do princípio orientador das determinações jurídicas (WEBER, 1993, p. 73-74).

\subsection{A moralidade subjetiva (Moralität)}

O conceito de liberdade deve progredir, da determinação do direito abstrato para a autodeterminação do sujeito. Diz Hegel: "En el derecho abstracto la voluntad sólo existía como personalidad, de ahora en adelante la tiene como su objeto propio. La subjetividad de la liberdad, que es de esta manera por sí infinita, constituye el principio del punto de vista moral" (HEGEL, 1988, § 104, p. 167). Um pouco mais adiante, diz ainda que "en el punto de vista moral la contingencia resulta superada, de manera tal que ella misma, en cuanto reflejada en sí misma e idéntica consigo, es la contingencia infinita que existe en el interior de la voluntad, su subjetividad" (p.168).

Cada sujeito deve reconhecer no outro o que quer para si enquanto sujeito e não como pessoa. Deve reconhecer também a liberdade como universal, isto é, discernir a vontade livre de todos os sujeitos que, sem exceção, são guiados por princípios e fins. É o "reconhecimento subjetivo da igualdade e da liberdade como princípios universais"(WEBER, 1993, p. 79).

$\mathrm{Na}$ moralidade, as vontades livres são mediadas e reconhecem subjetivamente o direito da vontade subjetiva como possibilidade da universalidade. Essa universalidade da liberdade tem validade apenas subjetiva. É apenas uma vontade em si, pois não há ainda a identificação do conceito da 
vontade com a vontade do sujeito. A moralidade é reflexividade, ou seja, é a ideia de uma consciência moral subjetiva que está ciente de que há um todo social objetivado. Portanto, é interiorização do princípio da liberdade a ser realizada a partir da efetivação do agir em relação aos outros. O homem refletido quer estar ciente de todos os seus atos. A esfera da moralidade é "el lado real del concepto de libertad" (HEGEL, 1988, § 106, p. 171).

A vontade subjetiva só reconhece aquilo que ela mesma quer e sabe diante das possíveis consequências, a terceiros, de um ato realizado, ou melhor, exteriorizado (HEGEL, 1988, § 113, p. 177). E, como tal, o direito da vontade subjetiva só se responsabiliza por aquilo que o sujeito sabia e queria fazer, ou seja, na medida em que a ação, enquanto resultado, e o propósito dessa ação se identificam. Afirma, "Toda acción, para ser moral, debe en primer lugar concordar con mi propósito, pues el derecho de la voluntad moral consiste en que sólo se reconoce en su existencia lo que interiormente existía como propósito" (HEGEL, 1988, § 114, agregado, p. 178) ${ }^{12}$. No direito da moralidade, aquilo que não foi possível ser previsto, não é imputado como responsabilidade da vontade. Aquilo que o sujeito reconhece como seu, que podia ser previsto, o propósito do seu agir considerando o resultado, é o que caracteriza a responsabilidade, que é, também, do próprio direito moderno.

A dificuldade reside na impossibilidade de prever as possíveis consequências de uma ação em sua totalidade. Então, posso julgar uma ação como moral, isto é, subjetivamente responsável pelas consequências, se essas foram previstas pelo sujeito por estar ciente (saber) dos danos possíveis a outros sujeitos e por tê-las, assim mesmo, querido realizá-las. Não é possível no direito da vontade moral e, assim, também para o direito liberal (WEBER, 1993, p. 8889) adotar uma perspectiva mais objetiva que considere também a universalidade do conceito. Não é possível incorporar nenhum princípio novo, como afirma Weber, nem considerar um contexto mais amplo, a não ser o conteúdo já determinado desde o primeiro momento da vontade livre. O que interessa a Hegel é estabelecer as condições subjetivas, restritas aos critérios jurídicos, da responsabilidade moral sem haver, assim, distinção entre o legal e o moral (WEBER, 1993, p. 89).

O segundo elemento constitutivo do direito da vontade livre é a intenção, que visa à universalização. A intenção é a universalização de minha ação, inicialmente querida só subjetivamente, enquanto propósito. Agora, inicia-se a universalização da minha ação, através da intenção, superando o

12 Aqui é oportuno adiantar que Hegel segue Kant na questão da autonomia da vontade na qual a diferença principal está no considerar os resultados das ações, se previstos, o sujeito agente como moralmente responsável em nível subjetivo (Cf. WEBER, 1993, p. 82). 
propósito e sua imediaticidade, pois passa a considerar, também, as conseqüências não previstas. $\mathrm{O}$ sujeito moral passa a ser responsável do bemestar também dos outros, já que a sua vontade, não mais imediata, está voltada a um fim universal.

O que vai possibilitar o encontro entre a vontade subjetiva particular e a universalização de suas possíveis consequências objetivas é a ideia do bem. Para Hegel (1988, § 129, p. 193), "El bien es la idea como unidad del concepto de la voluntad y de la voluntad particular". A ideia do bem é uma nova determinação da vontade livre no universal, onde "el bienestar no es un bien sin el derecho. Del mismo modo, el derecho no es el bien sin el bienestar" (HEGEL, 1988, § 130, p. 193). Isso aponta apenas novos níveis de determinação da ideia da liberdade, mantendo-se os conteúdos dados no direito da vontade moral. $\mathrm{O}$ bem continua sendo uma determinação universal abstrata, que como o essencial da vontade do sujeito particular "tem nele sua obrigação". "Lo esencial de la voluntad es para mí un deber" (HEGEL, 1988, § 133, p. 197) ${ }^{13}$.

O bem deve ser determinado para poder passar de um universal abstrato para um universal concreto. Isso caracteriza a passagem para a moralidade objetiva. "A função orientadora da ideia da liberdade, no direito moderno, e a consequente restrição da responsabilidade (ao nível das estruturas jurídicas), no que diz respeito à moralidade, é o que nos leva à eticidade" (WEBER, 1993, p. 93).

O conteúdo do direito abstrato é mantido na moralidade sem que ela acrescente qualquer princípio além daqueles dados pelo direito vigente. A moralidade se encontra restrita às "estruturas estabelecidas pelo direito, uma vez que as condições da responsabilidade moral coincidem com as condições da responsabilidade legal. [...] O direito dá todos os conteúdos à moralidade. Por outra, o direito é a regra da moralidade". E ainda "há uma coincidência entre as condições da moralidade e da legalidade. A moralidade é colocada ao nível da legalidade” (WEBER, 1993, p. 82-83). Há uma relação, que é dialética, no sentido do conteúdo do direito abstrato ser superado e guardado na moralidade. Isso também vai ocorrer no nível da eticidade. O que muda são os níveis de determinação.

\subsection{A moralidade objetiva (Sittlichkeit)}

13 É importante observar que na sequência do texto, Hegel reconhece o mérito de Kant de ter dado destaque ao significado do dever, porém o critica duramente por ter permanecido na pura abstração, vazio de conteúdo. Essa crítica vai ser melhor explicitada, mais adiante, ao analisarmos os principais pontos de divergência entre os dois filósofos. 
Como síntese dos dois itens anteriores, ou seja, o direito abstrato e a moralidade, surge a realização do conceito da liberdade em sua plenitude. É o espírito objetivo, concreto, que se faz presente nos costumes, nos hábitos, nas estruturas sociais, econômicas e políticas do povo. Trata-se da vontade livre subjetiva que se realiza concretamente no mundo através das ações e fins mediados politicamente. É a determinação e realização da liberdade no grau mais elevado, ou seja, concretamente, ao nível das instituições sociais. Seu conteúdo objetivo "[...] es por sí necesario y una existencia que se eleva por encima de la opinión subjetiva y del capricho: las instituciones y leyes existentes en y por sí" (HEGEL, 1988, § 144, p. 227) ${ }^{14}$. A moralidade objetiva ou eticidade é "el concepto de la libertad que ha devenido mundo existente y naturaleza de la autoconciencia" (HEGEL, 1988, § 142, p. 227) ${ }^{15}$.

Isso só é possível pela necessária unidade e identidade entre o bem da vontade subjetiva e o bem objetivo, e isso é a sua verdade. O bem, que é o fundamento desses dois pólos, deixa de ser um universal abstrato e fechado na consciência subjetiva e se determina como universal concreto, como moralidade social. Em outras palavras, é necessária a objetivação da moralidade subjetiva que comporta uma vontade subjetiva indeterminada, não esquecendo que tal vontade carrega consigo o conteúdo superado e guardado do direito abstrato. Para tornar-se efetiva, a ideia da liberdade deve ter autoconsciência de seu saber, de seu querer e de seus atos. No fundo, é a consciência moral institucionalizada nas formas sociais, que "[...] sabe da existência e da necessidade de atuação, no seu interior, de consciências morais subjetivas, singularizadas em indivíduos concretos" (FREITAG, 1992, p. 58). É o sujeito

${ }^{14}$ Um pouco antes, no acréscimo do parágrafo 141, p. 223, Hegel antecipa o que entende por eticidade e destaca, claramente, a relação entre o jurídico e o moral, que vale a pena transcrever aqui: "La unidad del bien subjetivo y del bien objetivo existente en y por sí es la eticidad, en la que se produce la reconciliación de acuerdo con el concepto. Si la moralidad es pues la forma de la voluntad según el lado de la subjetividad, la eticidad no es ya meramente la forma subjetiva y la autodeterminación de la voluntad, sino el tener como contenido su propio concepto, es decir la libertad. Lo jurídico y lo moral no pueden existir por sí y deben tener lo ético como sostén y fundamento. En efecto, al derecho le falta el momento de la subjetividad que la moral tiene, en cambío, exclusivamente para sí, por lo cual ninguno de los dos momentos tiene por sí realidad. Sólo lo infinito, la idea, es efectivamente real; el derecho sólo existe como rama de una totalidad, como planta que crece en torno a um árbol firme en y por sí". (O destacado, em itálico, é nosso).

15 No acréscimo deste parágrafo, Hegel pergunta, "O que é eticidade? Que minha vontade seja posta como adequada ao conceito e com isso superada e guardada sua subjetividade". Essa definição de Hegel não foi encontrada na edição espanhola citada. Talvez tenha sido omitida por falha de tradução ou redação. 
moral, enquanto membro e, portanto, uma parte dessa segunda natureza, que constitui o todo político, chamado por Hegel de substância ética. Esse sujeito deve ser guiado por normas e princípios éticos universais, consciente da liberdade de ação e da responsabilidade a ser assumida diante dessa mesma comunidade ética. Portanto, a realização da liberdade plena só é possível na convivência com os outros, na sua objetivação por indivíduos que pertencem a uma realidade ética. Será tarefa do Estado garantir tal liberdade, zelando pelos direitos e deveres do cidadão.

Há uma coincidência que é fundamental para o desenvolvimento estrutural da eticidade e sua própria possibilidade. Em outro sentido, a eticidade é o fundamento do âmbito jurídico e moral. Diz Hegel: "En esta identidad de la voluntad universal y particular coinciden por lo tanto el deber y el derecho; por medio de lo ético el hombre tiene derechos en la medida en que tiene deberes y deberes en la medida en que tiene derechos." (HEGEL, 1988, § 155, p. 235). Esta dependência mútua e coincidência dos direitos e deveres apontam para a realização e predominância da substancialidade ética e revela a coincidência necessária entre a moralidade e a legalidade. Continua Hegel (1988, § 155, p. 235), "En el derecho abstracto yo tengo un derecho y otro el deber correspondiente; en lo moral el derecho de mi propio saber y querer, así como el de mi bienestar, sólo debe ser objetivo e idéntico con los deberes".

A família é a primeira instituição social da eticidade ${ }^{16}$ e se caracteriza por ainda não ser mediada. Portanto, é tida como o "Espíritu ético inmediato o natural" (HEGEL, 1988, $\S 157$, p. 236). Isso se deve ao amor entre seus membros, no casamento, no qual o reconhecimento mútuo objetivado é sua unidade, e o direito, enquanto ordem jurídica, só intervém se essa unidade, ainda natural e imediata, for ameaçada. São, também, elementos constitutivos da família, a propriedade familiar, enquanto patrimônio, e a educação dos filhos na preparação para a conquista da autonomia e para a convivência social.

A unidade jurídica atingida pelo casamento, em que as vontades particulares aderem e consentem essa nova unidade, que é, principalmente, espiritual, irá possibilitar e contribuir para a realização da substancialidade ética. Por seus fins inerentes, a família é considerada, por Hegel, como a base do Estado.

Com a dissolução da família, os indivíduos passam a se relacionar com os outros indivíduos como independentes. Esse é o momento da sociedade civil, considerada como a segunda base ética do Estado, que deve mediar a individualidade concreta, em seus interesses e necessidades particulares, e a

16 Hegel dedica longas páginas aos três momentos do desdobramento da Eticidade (família, sociedade civil e Estado). Para nosso intento, apenas en passant, uma breve menção. 
forma da universalidade, expressa nas inter-relações do contexto social. A sociedade civil é o momento de mediação entre o individual e o coletivo. Ela é o lugar da diversidade, da procura pela satisfação das necessidades e interesses pessoais, que só pode realizar-se na medida em que a universalidade for interiorizada e assumida pela vontade particular. É o universal que deve existir concretamente na particularidade.

O problema de como harmonizar as contradições, de como conciliar os diferentes interesses particulares deste momento da sociedade civil, que é definido como "el campo de batalla del interés privado individual de todos contra todos" (HEGEL, 1988, § 289, p. 375), está na mediação da universalidade, que exige a abstração das necessidades materiais imediatas entre os indivíduos, ou seja, na restrição e determinação da vontade livre entre o conteúdo do dever e as formas do direito (WEBER, 1993, p. 117). Novamente aparece a coincidência e mútua relação entre direitos e deveres como possibilidade da liberdade.

As determinações da sociedade civil, ou seja, o sistema das necessidades, a administração da justiça e a administração pública, são alimentadas pelos deveres prescritos na ordem jurídica, fornecida pelo Estado de direito. A liberdade de cada cidadão, como membros de uma corporação, diante da multiplicidade de necessidades e diferenças naturais ou não, é garantida pela ação moral. O direito, na forma da lei, garante a justiça e deve ser reconhecido universalmente para poder se concretizar e restabelecer o equilíbrio entre os membros pertencentes a uma classe e, como tais, sujeitos de direitos que não são mais vontades imediatas.

Em torno disso vai se desenvolver a função da administração pública, através da polícia e das corporações, como a síntese dialética do sistema de necessidades e da administração da justiça. Cabe à administração pública garantir o exercício da liberdade de todos os indivíduos e, consequentemente, zelar pela ordem político-social. "O fato é que a sociedade civil está bem organizada, formal e juridicamente, mas, do ponto de vista da realização plena do princípio pressuposto, é ainda parcial. Não há elemento algum, na sociedade civil, capaz de realizar a essencialidade ética" (WEBER, 1993, p. 131). Portanto, a sociedade civil é a mediadora entre a família e o Estado. É o momento da negação do particular (família) que, embora como universal, só se realiza plenamente na negação da negação, isto é, no Estado.

O que interessa é, se é possível que todos tenham liberdade, como e onde ela pode ser realizada verdadeiramente. O que garante, segundo Hegel, é o Estado enquanto fundamento último e congregação dialética de todos os momentos constitutivos anteriores. Afirma, "El estado es la realidad efectiva de 
la idea ética, el espíritu ético como voluntad sustancial revelada, clara para sí misma, que se piensa y se sabe y cumple aquello que sabe precisamente porque lo sabe" (HEGEL, 1988, § 257, p. 318). Somente o cidadão que convive internamente na família, externamente nas corporações e, portanto, necessariamente como membro do Estado pode efetivar concretamente a sua liberdade. Em outras palavras, só há liberdade no Estado. Então, a estrutura da Filosofia do Direito é garantida pela ideia de Estado (Estado absoluto), que é a possibilidade, como ideia do dever-ser, e o lugar da realização da substancialidade ética.

Para garantir a liberdade individual, enquanto substancial, ou seja, para poder conciliar a vontade subjetiva com a vontade substancial, o Estado exige o cumprimento dos deveres estabelecidos pelo direito. Reaparece a restrição de direitos e deveres como forma de mediar os interesses individuais e a vontade substancial. No fundo, como diz Weber, é a tentativa de conciliar a liberdade e a necessidade através das mediações. "Liberdade é a necessidade de fazer o que é determinado pelo substancial, isto é, o Estado" (WEBER, 1993, p. 144). Então, a vontade substancial é a vontade particular que, através das instituições, integra a Constituição como a totalidade orgânica do Estado, isto é, como expressão do Espírito do povo. Com essa lei maior, o Estado pretende a realização universal da liberdade. Neste sentido, "o modelo de Estado instaurado pelo direito moderno encontra em Hegel plena justificação" (WEBER, 1993, p. 145).

\section{Considerações finais}

A partir do exposto, é possível perceber a existência de certas semelhanças e muitas diferenças entre os dois sistemas imponentes de Ética. Isso ficou mais evidente, pelo menos esta foi a intenção, no que diz respeito à relação entre o moral e o jurídico e o tratamento dado por Kant e, principalmente, por Hegel, em torno dos mesmos assuntos e objetivos filosóficos. Algumas comparações podem ser melhor explicitadas, inclusive alguns pontos da crítica de Hegel a Kant.

Ao falar sobre a ideia do bem, Hegel explicita o que entende por dever, definido, inicialmente, como "actuar conforme al derecho y preocuparse por el bienestar, tanto por el propio como por su determinación universal, el bienestar de los demás" (HEGEL, 1988, § 134, p. 197). Reconhece, com Kant, que o ponto de partida e fundamento está na vontade, isto é, na autodeterminação da vontade como raiz da ideia do dever (HEGEL, 1988, § 135, obs., p. 198). Essa interiorização do dever, da lei objetiva, como princípio regulador e expressão da 
lei universal a ser aceita e respeitada por todos, é produto da razão. Porém, Hegel critica Kant por ficar restrito ao dever pelo dever, que é mero ponto de vista moral abstrato, destituído de qualquer determinação de conteúdos, não chegando, assim, ao conceito de eticidade. Para Hegel, o dever pelo dever é um formalismo vazio, uma ausência de contradição, uma simples concordância formal consigo mesmo, uma indeterminação abstrata, que não pode ser usada na determinação de deveres particulares (HEGEL, 1988, § 135, obs., p. 198). Portanto, no imperativo categórico não há contradição, pois é uma mera identidade formal, vazia de conteúdo concreto, não ultrapassando, assim, o âmbito da moral subjetiva.

Para Kant, há uma separação entre ser e saber, onde o a priori da razão é o seu ponto de partida e fundamento. Para Hegel, não há a priori no conhecimento. Não podem ser separados a forma e o conteúdo. Seu ponto de partida é o ser puro, indeterminado, vazio, que, pelo movimento de mediação dialética, deve ser determinado concretamente. Portanto, não há para Hegel um a priori da razão, embora, em última análise, tudo seja produto da razão. Não é possível não levar em conta as circunstâncias da ação, ou seja, aquilo que caracteriza a contradição, para qualificá-la moralmente.

A autonomia da vontade, como autodeterminação do querer e saber, é um dos pontos retomados por Hegel da filosofia kantiana. Aqui, é importante insistir sobre em que medida há o risco de tornar a ação conforme o dever (as leis jurídicas) numa desresponsabilidade moral, ou seja, num mero legalismo. Para Kant, a autodeterminação da vontade não leva em conta os resultados das ações. O sujeito é responsabilizado moralmente somente quando a intenção de sua ação não foi determinada pelo critério formal e incondicionado do dever pelo dever. Se a intenção for de realizar o ato segundo as normas jurídicas, isso pode satisfazer o aspecto legal, mas leva a uma desresponsabilidade moral. A responsabilidade moral para Hegel está restrita ao saber e ao querer, ou seja, ao resultado da ação e a intenção do sujeito considerando o bem coletivo.

Diferentemente de Kant, que separa a moralidade da legalidade, a proposta hegeliana apresenta a moralidade ao nível da legalidade. "A moralidade do sujeito está intrinsecamente ligada ao respeito às estruturas estabelecidas pelo direito, uma vez que as condições de responsabilidade moral coincidem com as condições da responsabilidade legal", sustenta Weber. E conclui, "Em última instância, só pode tornar-se conteúdo de responsabilidade de cada pessoa aquilo que o direito prevê e impõe. Quer dizer, o direito dá todos os conteúdos à moralidade" (WEBER, 1993, p. 82-83). É claro que, ao nível da moralidade objetiva, tais conteúdos e princípios serão superados e guardados, 
isto é, novas determinações vão responder à necessidade do próprio sistema na efetivação da substancialidade ética.

Na moralidade, o que interessa à ética kantiana é a intenção subjetiva e não o resultado da ação do sujeito. Não interessam as circunstâncias do fato e as próprias consequências objetivas do ato. Hegel, que "nega a possibilidade da existência de uma consciência moral (subjetiva ou objetiva) fora da sociedade" (FREITAG, 1992, p. 69), considera o resultado da ação. Procura examinar o conteúdo, as possíveis consequências, também as não previstas pelo sujeito, para poder determinar como ação moralmente objetiva. É claro que, ao nível do direito abstrato e da moralidade, há uma restrição às estruturas jurídicas. O que, sem dúvida, abre margem para a justificação de atos sob a perspectiva meramente legalista, principalmente na adequação à mera forma da lei. O que deve ser destacado é que a simples aplicação da lei objetivamente vigente não garante ações justas e moralmente válidas nas quais se realize o princípio da liberdade e da igualdade.

Se pautarmos, por um lado, nossas decisões e ações pela simples conformidade ao dever, à lei, então temos, com Kant, um ato legal, mas não moral. O motivo da ação é lícito, mas é provocado de diferentes fontes, não restringindo-se ao respeito à lei moral. Se, por outro lado, procedermos conforme Hegel expõe, relativos ao direito abstrato e à moralidade, não iremos além dos conteúdos fornecidos pelo direito. Então, teremos, primeiramente, a mera legalidade e, no segundo movimento da vontade livre, a moralidade subjetiva. Já na eticidade, não pode haver separação entre moral e legal. Deve haver uma coincidência plena objetivada entre direitos e deveres, para a realização do princípio fundador, orientador e regulador da vontade: a ideia da liberdade. Pela ação e reflexão, o sujeito reconhece as leis objetivadas na comunidade e passa a identificar nelas a possibilidade de realizar seus interesses pessoais. No instante em que coincidir a vontade moral subjetiva com as leis vigentes da sociedade, traduzidas em ações particulares, instaura-se a vida ética. Não é possível o sujeito formar uma consciência moral fora da convivência social.

Para Hegel, na vontade livre imediata ocorre a determinação pelas leis jurídicas abstratas. No momento da moralidade, essas leis são interiorizadas subjetivamente como autodeterminação da vontade e o resultado é uma consciência moral subjetiva que passa a considerar o bem-estar das outras vontades. É o direito da moralidade subjetiva, como categoria jurídica, isto é, limitado à estrutura e regras jurídicas da ação, "[...] é mais um direito da desresponsabilização do que da responsabilização", argumenta Weber (1993, p. 85). Por outro lado, o direito da moralidade, continua Weber, "se refere mais 
àquilo pelo qual alguém não pode ser responsabilizado do que àquilo pelo qual alguém pode ser responsabilizado. Hegel delimita as exigências morais através das regras jurídicas. O critério jurídico é o que determina, em última análise, as obrigações morais" (WEBER, 1993, p. 85).

Então, o sujeito agente, considerando o conteúdo, não vai ficar só no aspecto legal, como o é para Kant, em que há uma clara distinção entre a estrutura jurídica (Direito) e a ética (Moral). É exatamente por levar em conta o conteúdo no qual o direito procura abarcar, mesmo que de modo restrito em função das consequências não previstas no saber e querer subjetivo, que reside a possibilidade da moralidade e, na unidade com o conceito, a concretização da eticidade. Há uma organicidade do sistema. Cada instituição sustenta, pressupõe o funcionamento de todas as outras, na medida em que sustenta o seu próprio funcionamento. Essa ideia de organicidade, que é um todo indeterminado e que deve ser reconstruído a partir das mediações, na qual o que não está no começo não pode mais entrar. Nesse sentido, cada momento das diversas formas do direito são momentos integrantes de determinação e realização da liberdade.

Com o ponto de vista organicista, em que a ideia da comunidade popular é entendida como uma coletividade, um todo orgânico, vivo e histórico, e não como a soma de indivíduos isolados, Hegel aponta para uma vida prática a dimensão da eticidade. Isso é bem diferente do ponto de vista atomista (BOBBIO, 1981, p. 36-37), limitado à distinção direito-moral. A ética, enquanto moralidade objetiva, refere-se ao campo social e ultrapassa o dualismo tradicional direito-moral.

A estrutura tripartida, apresentada na Filosofia do Direito, mostra, segundo Bobbio (1981, p. 77), uma mudança fundamental e radicalmente inovadora com relação ao sistema kantiano da Metafísica dos Costumes. A moralidade está colocada depois do direito privado e antes do Estado e não depois do direito privado e do direito público. A distinção kantiana entre legalidade e moralidade "[..] retirava a esfera do direito (simultaneamente privado e público) da esfera da moral (BOBBIO, 1981, p. 77). No caso de Hegel, Bobbio sustenta que, "o salto qualitativo ocorre na passagem da esfera em que se desenrola a vida privada (compreendendo, portanto, tanto o direito em seu caráter específico de direito privado quanto a moral) para aquela em que se desenvolve a vida do membro de uma sociedade organizada, ou do cidadão" (BOBBIO, 1981, p. 77).

A sociedade e o Estado, para Kant, é uma só coisa. E o Estado está submisso aos princípios éticos. O que se percebe em Hegel é a novidade da dimensão da sociedade civil e separada do Estado. Há um predomínio do 
político sobre a ética, isto é, no Estado há um predomínio sobre a estrutura da ética. $\mathrm{O}$ instrumento com o qual o Estado exprime sua vontade é a lei e não o costume. A Constituição deve refletir o Espírito do povo, e ela é tida como a forma jurídica própria do Estado ético.

A ética hegeliana é repleta de mediações, de movimentos dialéticos que cristaliza a relação conflituosa, contraditória entre o indivíduo e a coletividade, ou melhor, entre a própria vontade do sujeito na busca da realização da ideia da liberdade. Não é a liberdade do indivíduo, em sua particular individualidade, que atua subjetivamente pelo arbítrio, afastado do mundo material, concreto. Para Hegel, a liberdade tem uma dimensão mais ampla em que entra o sujeito no seu estar-no-mundo procurando realizar-se concretamente a todo instante. É o ser humano que reconhece o direito de todos, ciente da sua realidade e de sua condição humana que vai desde a necessidade de confirmar a sua liberdade pelo domínio da natureza, até o reconhecimento do direito dos outros. É no contraditório que reside a força propulsora de superação, enriquecimento e elevação ao nível de uma liberdade autoconsciente, somente possível de ser efetivada no Estado.

\section{Referências bibliográficas}

BOBBIO, Norberto. Direito e Estado no pensamento de Emanuel Kant. Brasília: Edunb, 1984.

$\overline{\mathrm{UNESP}}^{\cdot}$. 1981.

COLOMER, E. El pensamiento alemán de Kant a Heidegger. Barcelona:Herder, 1986. v. 1,2.

DOTTI, Jorge Eugenio. Dialectica y Derecho. Buenos Aires: Hachette, 1983.

FREITAG, Barbara. Itinerário de Antígona: a questão da moralidade. Campinas: Papirus, 1992.

HEGEL, G.W.F. Principios de la filosofía del derecho. Barcelona: EDHASA, 1988.

KANT, I. Crítica da razão prática. Lisboa: Edições 70, 1989.

1992.

- Fundamentação da metafísica dos costumes. Lisboa: Edições 70,

WEBER, Thadeu. Hegel: liberdade, estado e história. Petrópolis: Vozes, 1993.

Contribuição dos autores:

Idalgo Jose Sangalli e Mateus Salvadori participaram da discussão, revisão e redação do artigo.

Todos os autores aprovaram a versão final do texto. 